\title{
Genetic and environmental factors that influence production and quality of milk of Alpine and Saanen goats
}

\author{
L.F. Brito ${ }^{1}$, F.G. Silva ${ }^{1}$, A.L.P. Melo ${ }^{1}$, G.C. Caetano ${ }^{1}$, R.A. Torres ${ }^{1}$, \\ M.T. Rodrigues ${ }^{1}$ and G.R.O. Menezes $^{2}$ \\ ${ }^{1}$ Departamento de Zootecnia, Universidade Federal de Viçosa, \\ Viçosa, MG, Brasil \\ ${ }^{2}$ Embrapa Gado de Corte, Campo Grande, MS, Brasil \\ Corresponding author: L.F. Brito \\ E-mail: 1fbritozootecnia@yahoo.com.br
}

Genet. Mol. Res. 10 (4): 3794-3802 (2011)

Received May 27, 2011

Accepted October 21, 2011

Published December 14, 2011

DOI http://dx.doi.org/10.4238/2011.December.14.9

\begin{abstract}
Data from 1279 lactations of 783 Alpine and Saanen goats of the herd of our university in Minas Gerais, Brazil, were used to study environmental effects on and to estimate genetic parameters for milk production until 270 days of lactation (MP270) and for production and percentages of fat (PFAT and \%FAT), protein (PPROT and \%PROT), lactose (PLACT and \%LACT), and total dry extract (PEXTR and \%EXTR). Environmental effects were estimated by a statistical model that included contemporary group effect, type of kidding, genetic grouping, and kidding order. A multi-trait animal model with animal and permanent environment random effects was used to estimate genetic parameters and the significant environmental effects (fixed). Contemporary group influenced all traits; genetic grouping did not influence \%LACT; type of kidding did not influence PFAT, \%PROT or $\%$ LACT, and kidding order did not influence $\%$ FAT or $\%$ EXTR. Heritability and repeatability estimates were, respectively, 0.19 and 0.37 (MP270); 0.10 and 0.20 (PFAT); 0.12 and 0.24 (PPROT); 0.15 and
\end{abstract}


0.27 (PLACT); 0.13 and 0.24 (PEXTR); 0.21 and 0.34 (\%FAT); 0.39 and 0.44 (\%PROT); 0.17 and 0.29 (\%LACT); 0.31 and 0.47 (\%EXTR). Estimates of genetic correlations among MP270 and production of milk constituents were positive and high, but correlations between MP270 and \%FAT, MP270 and \%PROT, MP270 and \%ESTR were moderate and negative. These heritability estimates show that satisfactory genetic gains can be obtained by selection, especially for milk constituents.

Key words: Genetic correlation; Heritability; Repeatability; Selection

\section{INTRODUCTION}

Goat milk is a nutrient rich food with unique traits. Among nutritional and therapeutical advantages, goat milk contains high quality proteins and a great content of minerals and vitamins, in addition to better digestibility of lipid fraction and the lower allergenicity of protein fraction, when compared to cow milk.

Goats are well adapted to many different environments and they are very versatile as producers of food and raw matter such as milk, meat and skin. In this context, goat livestock is promising and strategic for a country like Brazil, which has wide ecosystem diversity and different social-economical realities.

Brazil has approximately 10 million goats and produces 135 million of liters of goat milk, which makes it the greatest producer of milk goats on the American continent (Food and Agriculture Organization, 2008). The increasing demand for quality milk products has stimulated the market. Quality is basically determined by two factors: microbiological control and contents of milk constituents. Microbiological control is linked mainly to the mammary sanitary system, indicated by somatic cell count and hygiene during obtainment and processing of milk. Contents of milk constituents are quantified by laboratorial analyses and they are related to genetics and environmental factors, as for example animal nutrition.

Although some Brazilian producers are not in fact paid based on the milk's composition, this factor has become an international tendency. Therefore, this aspect should be considered in genetic improvement programs in Brazil.

To study the effects which influence traits which are going to be selected is important to define the statistical model to be used in genetic parameter estimation, which will guide the establishment of goat genetic improvement programs.

However, there is limited information on the factors which influence productive traits of goats, especially the ones regarding the composition of milk, and most of the studies only concern the effects on milk production and length of the lactation period alone.

This paper was carried out to identify environmental factors which influence production and contents of milk constituents and milk production until 270 days of lactation, in addition to estimating genetic parameters for those traits in Saanen and Alpine goats.

\section{MATERIAL AND METHODS}

The data base originally contained 3399 lactations referent to dairy control performed from 2000 to 2010 in Saanen and Alpine genetic grouping goats, which belonged to goat sec- 
tion of Universidade Federal de Viçosa (UFV/MG).

Milk control was performed weekly. Milking was carried out twice daily. Animals were kept in collective stalls under free stall system and were fed diets based on corn silage and hay, as roughage, and concentrate mixture, available according to the nutritional needs of the animals.

For a greater reliability of the data records, lactation of animals was considered with a kidding order from 1 to 6 , first milk control performed before the 35th lactation day, lactation length longer than 100 days, yields greater than $100 \mathrm{~kg}$ and control intervals shorter than 28 days. After those restrictions, there remained only 1279 lactations from 783 goats, out of which 519 were primiparous.

Animals were classified in 9 genetic groupings (GG), according to breed composition: composition of 50\% Alpine (GG1); 51 to 81\% Alpine (GG2); 82 to 93\% Alpine (GG3); more than 93\% Alpine (GG4); 51 to 81\% SRD (GG5); more than 81\% SRD (GG6); 50\% Saanen (GG7); 51 to $81 \%$ Saanen (GG8) and more than 93\% Saanen (GG9). Data of this work are from exclusively Alpine or Saanen animals and SRD is the denomination used in cases without information on the reproducer used. Collection of milk samples were done monthly and sent to Milk Quality Lab for quantification of contents of fat, protein, lactose and total dry extract.

Menezes et al. (2010), studying lactation persistence measures of Saanen goats under random regression model, suggested using some adaptations of the measures found in the literature on dairy bovines, as for the example, the use of 268 days of lactation length, ( 9 months), rather than 305 days. In this paper the total milk production was estimated until 270 days of lactation. MP270 was estimated based on the following formula:

$$
\text { MP270 }=\sum_{i=1}^{n-1}\left[\left(\frac{\text { pldc }_{i}+\text { pldc }_{i+1}}{2}\right) * I_{i+1}\right]
$$

where: MP270 = accumulated milk production until 270 days of lactation; $p l d c_{i}=$ milk production under milk control i; pld $_{i+1}=$ milk production in the next milk control; $I_{i, i+1}=$ interval in days between two consecutive controls.

Production of milk constituents were obtained through the product of MP270 by the average percentage of fat, protein, lactose and total dry extract.

To check the influence of environmental effects, analyses of variance for unbalanced data was done by the generalized least square method by the procedure GLM of SAS ${ }^{\circledR}$ (1995). The model used to explain variation of the traits under study was:

$$
\mathrm{Y}_{\mathrm{ijkl}}=\mu+\mathrm{CG}_{\mathrm{i}}+\mathrm{TK}_{\mathrm{j}}+\mathrm{GG}_{\mathrm{k}}+\mathrm{KO}_{1}+\varepsilon_{\mathrm{ijkl}}
$$

where, $y_{i j k l}$ observation of the animal from the contemporary group $i$, with type of kidding $j$, of genetic grouping $k$ and kidding order $1 ; m=$ overall mean; $C G_{i}=$ effect of the contemporary group I, formed by the year and calving season (1 to 19$) ; T K_{j}=$ effect of type of kidding $j$ (simple or double); $G G_{k}=$ effect of genetic grouping $\mathrm{K}$ (1 to 9); $K O_{l}=$ effect of kidding order (1 to 6), and $e_{i j k l}=$ random error associated to each observation $y_{i j k l}$.

Estimates of components of variance and genetic parameters were obtained by using application REMLF90, described by Misztal (2002), in which the methodology of restricted maximum likelihood (REML) and the algorithm of Expectation maximization (EM) were used. 
Two multi-trait genetic evaluations were done, one for MP270 and production of milk constituents (fat, protein, lactose, and total dry extract) and another for MP270 and for percentages of milk constituents. Evaluations were made according to the animal model, considering animal and permanent environmental random effects; and the fixed effects which were significant for each trait in the analysis of environmental effects.

The matrix model used in this study can be described by:

$$
\mathrm{Y}=\mathrm{X} \beta+\mathrm{Zg}+\mathrm{Wp}+\varepsilon
$$

where: $y=$ vector of observations $(\mathrm{n} \times 1) ; X=$ incidence matrix of fixed effects $(\mathrm{n} \times \mathrm{f}) ; \beta=$ vector of fixed effects $(\mathrm{f} \times 1) ; Z=$ incidence matrix of direct additive genetic effects $(\mathrm{n} \times \mathrm{N})$; $g=$ vector of direct additive genetic effects $(\mathrm{N} \times 1), \mathrm{g} \sim \mathrm{N}\left(0, \mathrm{~A} \sigma_{\mathrm{g}}^{2}\right) ; W=$ incidence matrix of permanent environmental effects $(\mathrm{n} \times \mathrm{No}) ; p=$ vector of permanent environmental effects (No $\times 1), \mathrm{p} \sim \mathrm{N}\left(0, \mathrm{I} \sigma_{\mathrm{p}}^{2}\right) ; \varepsilon=$ vector of residual effects $(\mathrm{n} \times 1), \varepsilon \sim \mathrm{N}\left(0, \mathrm{I} \sigma_{\mathrm{e}}^{2}\right)$; where $n=$ number of observations; $f=$ number of levels of fixed effects; $N^{\circ}=$ number of animals with observation and $N=$ total number of animals, related in the matrix of the numerator of coancestry of Wright's coefficient (A).

\section{RESULTS AND DISCUSSION}

Values of means, number of observations, maximums, minimums and coefficient of variation were within the acceptable standards for the species (Table 1).

Prata et al. (1998), when they analyzed characteristics of milk of Saanen goats from southeastern Brazil, found the following average values for milk composition: $3.27 \%$ for total protein; $3.74 \%$ for fat; $4.35 \%$ for lactose; $0.74 \%$ for minerals and $88.49 \%$ for water.

Vázquez et al. (2009) analyzed composition of milk of Saanen goats from herds in Guanajuato (Mexico) and found values of 2.72 and $3.24 \%$ for average contents of protein and fat, respectively.

Table 1. Averages, number of observations, maximum, minimal and coefficient of variation (CV\%) for the traits milk production until 270 days (MP270); production and percentage of fat, protein, lactose and total dry extract (EXTR).

\begin{tabular}{|c|c|c|c|c|c|}
\hline Trait & Number & Mean & Minimum & Maximum & $\mathrm{CV}(\%)$ \\
\hline MP270 (kg) & 1279 & 440.87 & 102.25 & $1,278.85$ & 43.87 \\
\hline Fat production $(\mathrm{kg})$ & 1279 & 15.26 & 1.88 & 45.91 & 47.36 \\
\hline Protein production $(\mathrm{kg})$ & 1279 & 13.25 & 2.68 & 34.99 & 47.93 \\
\hline Lactose production $(\mathrm{kg})$ & 1279 & 17.70 & 0.91 & 49.87 & 49.21 \\
\hline EXTR production $(\mathrm{kg})$ & 1279 & 50.01 & 9.30 & 127.45 & 47.01 \\
\hline Fat percentage & 1279 & 3.73 & 1.38 & 8.89 & 19.18 \\
\hline Protein percentage & 1279 & 3.20 & 2.17 & 6.22 & 10.29 \\
\hline Lactose percentage & 1279 & 4.23 & 0.67 & 5.02 & 8.59 \\
\hline EXTR percentage & 1279 & 12.09 & 6.81 & 17.38 & 7.93 \\
\hline
\end{tabular}

Effect of year-season was significant for all the traits. This effect is especially due to the variations of climate, food nutritional quality and composition of herd. According to Quittet (1978), food intake on rainy days or days with strong heat can be null. Appleman and Delouche (1958) reported that goats presented maximal intake at $0^{\circ}$ to $10^{\circ} \mathrm{C}$, gradually decreasing as temperature increased up to $40^{\circ} \mathrm{C}$. Year-season effect affected milk production, which was observed in tropical native breeds and subtropical in their origin countries (Singh 
et al., 1970; Prakash et al., 1971; Barhat and Chowdhary, 1978; Mavrogenis et al., 1984), in specialized goats in the United States (Alderson and Pollak, 1980) and native, exotic goats and their crossbreds, in a total of 16 genetic groupings in Mexico (Montaldo et al., 1981).

Genetic grouping was not significant only for milk lactose percentage. This showed that the different genetic composition of the animals influenced milk production and composition, which is an important factor to be considered in the genetic evaluation of those traits. According to Maldonado et al. (1998), environmental factors which affect milk lactose content have been poorly studied, perhaps because of its lesser variation according to nutritional and environmental factors.

Type of kidding did not influence fat yield and percentages of protein and lactose. Influence of type of kidding, simple or multiple, on milk yield has previously been verified by some authors, explained by the presence of the hormone placental lactogen, progesterone and prolactin during gestation, which are mammary gland stimulants, Moreover, they differ in quantity according to the type of gestation, simple or multiple. Also, they might affect milk production during lactation and simultaneous pregnancies (Sands and Mcdowell, 1978; Analla et al., 1995 and Browning et al., 1995).

According to Galina et al. (1995), multiple kidding can increase the interval of posterior kidding by extending it due to stress of the goat, as to keep the pregnancy of one or more does there is a greater mobilization of nutrients for gestation and lactation, making it necessary to have a greater period of recovery of the doe until the next conception. Therefore, if the goat has not properly recovered, this can harm subsequent lactation.

In the herd of this study, kids received artificial suckling since their birth. In these cases, according to Pimenta Filho et al. (2004), even in multiple kidding, goats receive the same stimulus (milking). Therefore, the effect of the type of kidding occurred more because of the differences during pregnancy than in lactation. Perhaps, because of this, it was not possible to verify the significant effect of the type of kidding on some milk constituents.

Lactation order did not influence percentages of fat and total dry extract. However, Rodrigues et al. (2006), in a study with Saanen goats observed significant effect of lactation order on total milk yield and on percentages of fat, lactose and total solids. Zeng and Escobar (1995) observed that the greatest milk yield occurred with goats from the second lactation. According to Knight and Peaker (1982), this result can be explained by the fact that older goats present greater udder volume than goats of first lactation, i.e., the proportion of mammary alveoli which are developed in previous lactations do not regress completely, but it is added to those developed in subsequent lactations, increasing secretory parenchyma.

Kala and Prakash (1990) explained that the lowest percentages of constituents observed in the milk of goats from previous lactations are caused by the effect of dilution, i.e., goats produced more milk, directly reflecting on composition and decreasing their concentration in the milk.

Overall, percentages of milk constituents were less influenced by environmental effects. This could have occurred because it is a fraction of two traits and the variations are small because of the scale.

Most of estimates for heritability and repeatability of the traits were small (less than 0.20 ), therefore, gains obtained by selection will be smaller. However, heritabilities for percentage of constituents were greater, reaching 0.39 for protein percentage (Table 3 ).

According to Santos and Fonseca (2002), in Brazil, total milk yield and fat content are the traits most emphasized by milk control services, whereas many countries, in recent years, 
have valued protein content, using this criterion for payment systems per quality. According to Monards (1998), this tendency is explained because, while fat had its preference reduced by population consumption habits, protein has been valued for being a determinant of industrial yield of dairy products.

Table 2. Summary of analyses of variance for traits milk production until 270 days (MP270) and production and percentage of fat, protein, lactose and total dry extract.

\begin{tabular}{lcccc}
\hline Trait & \multicolumn{4}{c}{ Cause of variation } \\
\cline { 2 - 5 } & Contemporary group & Genetic grouping & Type of kidding & Order of kidding \\
\hline d.f. & 18 & 8 & 1 & 5 \\
MP270 & $*$ & $*$ & $*$ & $*$ \\
Fat yield & $*$ & $*$ & NS & $*$ \\
Protein yield & $*$ & $*$ & $*$ & $*$ \\
Lactose yield & $*$ & $*$ & $*$ & $*$ \\
Dry extract yield & $*$ & $*$ & $*$ & NS \\
Fat percentage & $*$ & $*$ & NS & $*$ \\
Protein percentage & $*$ & $*$ & $*$ & NS \\
Lactose percentage & $*$ & NS & & $*$ \\
Dry extract percentage & $*$ & $*$ & & $*$
\end{tabular}

$* \mathrm{P}<0.05 ; \mathrm{NS}=$ non-significant; d.f. $=$ degree of freedom.

Table 3. Estimates of additive genetic and permanent environment variance components, heritability $\left(\mathrm{h}^{2}\right)$ and repeatability $(\mathrm{t})$.

\begin{tabular}{lllll}
\hline Trait & $\sigma_{\mathrm{a}}^{2}$ & $\sigma_{\mathrm{p}}^{2}$ & $\mathrm{~h}^{2}$ & 0.19 \\
\hline MP270 & 6,458 & 6,231 & 0.10 & 0.37 \\
Fat yield & 4,638 & 4,558 & 0.12 & 0.20 \\
Protein yield & 4,228 & 4,085 & 0.15 & 0.24 \\
Lactose yield & 9,815 & 7,959 & 0.13 & 0.27 \\
Dry extract yield & 60.06 & 55.80 & 0.21 & 0.39 \\
Fat percentage & $0.9001 \mathrm{E}-05$ & $0.5368 \mathrm{E}-5$ & 0.17 & 0.34 \\
Protein percentage & $0.377 \mathrm{E}-05$ & $0.479 \mathrm{E}-06$ & 0.44 \\
Lactose percentage & $0.1674 \mathrm{E}-05$ & $0.1152 \mathrm{E}-05$ & 0.31 & 0.29 \\
Dry extract percentage & $0.2574 \mathrm{E}-04$ & $0.1337 \mathrm{E}-04$ & & 0.47 \\
\hline
\end{tabular}

Selection for milk yield increase has been performed for quite some time; however selection to improve goat milk quality by increase of the content of its constituents is something rather new in Brazil. Therefore, for these traits, there is still a component of additive genetic variance proportionally greater to be exploited by selection.

Most estimates of repeatability were small, so these values suggest that one single determination of the traits studied might not accurately represent performance of animals in further lactations.

Heritability estimated for milk production was low but within the interval of estimates observed in literature, lower than 0.296 reported by Gonçalves et al. (2001) and greater than 0.09 reported by Ribeiro (1997), who attributed this low value to the small number of study observations.

In the literature, few studies have presented estimates of heritability and repeatability for traits of goat milk composition. Analla et al. (1996), working with data of milk production of Murciano-Granadina goats in Spain, presented estimates of heritability and repeatability of 0.17 and 0.36 for milk production, 0.14 and 0.33 for fat percentage and 0.22 and 0.41 for 
protein percentage, respectively. Breznik et al. (2000), estimating components of variance for lactose percentage by using repeatability model in goats from Sloven, found heritability and repeatability equal to 0.23 and 0.34 . Bélichon et al. (1999) analyzed records of 33,431 and 20,700 Alpine and Saanen goats and found heritabilities of 0.34 and $0.32 ; 0.36$ and $0.34 ; 0.37$ and 0.40 for milk, protein and fat productions, respectively. Vázquez et al. (2010) found values of 0.17; $0.19 ; 0.17 ; 0.32$ and 0.38 for estimates of heritability of milk production performed at 305 days lactation, for fat production, protein yield, fat percentage and protein percentage, respectively.

Variations on estimates of heritability are expected because they are a relationship between two components of variance, which are particular for a given population in a certain environment in a definite time (Falconer, 1960).

Estimates of genetic correlations among milk production (MP270) and the yield of milk components and between MP270 and the percentages of milk components are presented in Table 4.

All correlations among yields of milk, fat, protein, lactose and total dry extract were high, ranging from 0.8623 for MP270 and fat yield to 0.9846 for MP270 and lactose yield.

Table 4. Estimates of genetic correlation among milk yield (MP270) and yields of milk constituents (above diagonal) and among MP270 and percentages of milk constituents (below diagonal).

\begin{tabular}{lccccc}
\hline & MP270 & Fat & Protein & Lactose & Dry extract \\
\hline MP270 & & 0.8623 & 0.9585 & 0.9846 & 0.9720 \\
Fat & -0.4725 & 0.6059 & 0.9338 & 0.8788 & 0.9529 \\
Protein & -0.4661 & 0.1968 & 0.0546 & 0.9403 & 0.9825 \\
Lactose & 0.1511 & 0.9120 & 0.7927 & 0.4255 & 0.9777 \\
Dry extract & -0.4384 & & & \\
\hline
\end{tabular}

Direction and magnitude of genetic correlation coefficient among two traits were used as a guide in a selection program. When coefficient of the correlation is high and favorable, it is possible to apply selection in only one of the traits aiming at the simultaneous improvement of the other. Therefore, based on the values of estimate genetic correlations, it can be inferred that when selecting for increase of milk yield, it will also be indirectly selecting for increase of milk constitutes yield.

Vázquez et al. (2009), estimated genetic correlation of 0.72 for milk and fat yield; 0.87 for milk and protein yield and 0.80 for fat and protein yield.

Most genetic correlations between MP270 and percentages of milk constituents were negative, indicating that some genes which determine increase of milk yield also act on the reduction of fat contents, protein and total dry extract in the milk.

Analla et al. (1996) found a genetic correlation of -0.89 between milk yield and fat percentage; -0.65 between milk yield and protein percentage and 0.93 between fat and protein percentages. Vázquez et al. (2009), found values of $-0.24 ;-0.30 ; 0.50$ for estimates of genetic correlation between milk production and fat percentage, milk production and protein percentage and percentages of fat and protein, respectively.

Estimates of genetic correlation between milk production and content of its constituents are important pieces of information, because when animals are selected and reproducers are chosen, frequently, more than one trait is used as a criterion of decision, depending on its economic importance, therefore it is necessary to define which weight should be given to milk yield and to the contents of milk constituents because quantity as well as quality of milk are important for the production system. 
According to Ribeiro (2008), most of the milk commercialized in the fluid form in Brazil is neither paid for, based on its chemical composition nor for microbiological quality. However, the author highlights that gains with selection are obtained in the long term, and it is necessary to define in advance the objectives which will meet market requirements.

\section{CONCLUSION}

Analyses of environmental effects show the importance of these factors on traits studied and on accurate genetic evaluations. Estimates of genetic parameters indicate that satisfactory genetic gains can be obtained by selection based on these traits, especially for fat content, protein and total dry extract in milk. Selection criteria used must meet the objectives of improvement of quantity and quality of goat milk.

\section{REFERENCES}

Alderson A and Pollak EJ (1980). Age-season adjustment factors for milk and fat of dairy goats. J. Dairy Sci. 63: 148-151. Analla M, Sanchez-Palma A, Muñoz-Serrano A and Serradilla JM (1995). Simulation analysis with BLUP methodology of different data structures in goat selection schemes in Spain. Small Rum. Res. 17: 51-55.

Analla M, Jimenez-Gamero I, Munoz-Serrano A, Serradilla JM, et al. (1996). Estimation of genetic parameters for milk yield and fat and protein contents of milk from murciano-granadina goats. J. Dairy Sci. 79: 1895-1898.

Appleman RD and Delouche JC (1958). Behavioral, physiological and biochemical responses of goats to temperature $0^{\circ}$ to $40^{\circ} \mathrm{C}$. J. Anim. Sci. $17: 326-335$.

Barhat NK and Chowdhary MS (1978). Factors affecting some production traits in Rajasthani goats. Ind. J. Dairy Sci. 31: 185-188.

Bélichon S, Manfredi E and Piacère A (1999). Genetic parameters of dairy traits in the Alpine and Saanen goat breeds. Genet. Cel. Evol. 30: 529-534.

Breznik S, Malovrh S, Kovac M et al. (2000). Additive genetic and environmental variance components for milk traits in goat with test day model. Zootehnika 76: 61-66.

Browning R, Leite-Browning ML and Sahlu T (1995). Factors affecting standardized milk and fat yields in Alpine goats. Small Rum. Res. 18: 173-178.

Falconer DS (1960). Introduction to Quantitative Genetics. 1st edn. Ronald Press, Edinburg.

Food and Agriculture Organization - FAO (2008). FAOSTAT - FAO Statistics Division / ProdSTAT: Livestock (Animals and Primary). Available at [http://faostat.fao.org/site/497/default.aspx]. Accessed April 15, 2008.

Galina MA, Silva E, Morales R and Lopez B (1995). Reproductive performance of Mexican dairy goats under various management systems. Small Rum. Res. 18: 249-253.

Gonçalves HC, Silva MA, Wechsler FS and Ramos AA (2001). Fatores genéticos e de meio na produção de leite de caprinos leiteiros. Rev. Bras. Zootec. 30: 719-729.

Instituto Brasileiro de Geografia e Estatística - IBGE (2006). Censo Agropecuário 2006: Resultados Preliminares. IBGE, Rio de Janeiro.

Kala SN and Prakash B (1990). Genetic and phenotypic parameters of milk yield and milk composition in two Indian goats breeds. Small Rum. Res. 3: 475-484

Knight CH and Peaker M (1982). Development of the mammary gland. J. Reprod. Fert. Camb. 65: 521-526.

Maldonado J, Gil A, Narbona E and Molina JA (1998). Special formulas in infant nutrition: a review. Early Hum. Dev. 53: S23-S32.

Mavrogenis AP, Constantinou A and Louca A (1984). Enviromental and genetic causes of variation in production traits of Damascus goats. 2. Goat productivity. Anim. Prod. 38: 99-104.

Menezes GRO, Torres RA, Sarmento JLR, Rodrigues MT, et al. (2010). Avaliação de medidas da persistência da lactação de cabras da raça Saanen sob modelo de regressão aleatória. Rev. Bras. Zootec. 39: 1691-1698.

Misztal I (2002). REMLF90 Manual, 2002. Available at [http://nce.ads.uga.edu/ ignacy/numpub/blupf90/docs/remlf90. pdf]. Accessed March 15, 2008.

Monardes H (1998). Programa de Pagamento de Leite por Qualidade em Quebec, Canadá. Simpósio Internacional Sobre Qualidade do Leite. Universidade Federal do Paraná, Curitiba, 40-43. 
Montaldo H, Tapia G and Juárez A (1981). Algunos factores geneticos y ambientales que influen sobre la producción de leche y el intervalo entre partos en cabras. Tec. Pec. Mex. 41: 32-44.

Pimenta Filho EC, Sarmento JLR and Ribeiro MN (2004). Efeitos genéticos e ambientais que afetam a produção de leite e duração da lactação de cabras mestiças no estado da Paraíba. Rev. Bras. Zootec. 33: 1431.

Prakash C, Acharya RM and Dhillon JS (1971). Sources of variation in milk production in Beetal goats. Indian J. Anim. Sci. 41: 356-360.

Prata LF, Ribeiro AC, Rezende KT, Carvalho MRB, et al. (1998). Composition, nitrogen fractions and physico-chemical characteristics of saanen goat's milk: southeastern region, Brazil. Cienc. Tecnol. Aliment. 18: 428-432.

Quittet E (1978). La cabra. Guia Practica para el Ganadero. 1st edn. Mundi-Prensa, Madrid.

Ribeiro AC (1997). Estudo dos Efeitos Genéticos e de Ambiente Sobre Características de Importância Econômica em Caprinos da Raça Saanen. Master's thesis, Universidade Estadual Paulista "Julio de Mesquita Filho", Jaboticabal.

Ribeiro AC (2008). Melhoramento Animal e a Qualidade do Leite dos Caprinos no Brasil. Anais do VII Simpósio Brasileiro de Melhoramento Animal. São Carlos.

Rodrigues L, Spina JR, Teixeira IAMA, Dias AC, et al. (2006). Produção, composição do leite e exigências nutricionais de cabras Saanen em diferentes ordens de lactação. Acta Sci. Anim. Sci. 28: 447-452.

Sands M and McDowell RE (1978). The Potential of the Goat for Milk Production in the Tropics. Cornell University, Ithaca.

Santos MV and Fonseca LF (2002). $2^{\circ}$ Curso On-line de Qualidade do Leite. Available at [http:www.milkpoint.com.br]. Accessed April 20, 2002.

SAS Institute (1995). SAS/ETS User's Guide. Version 6. 2nd edn. Cary.

Singh RN, Acharya RM and Biswas DK (1970). Evaluation of genetic and non-genetic factors affecting some economic traits in goats. Acta Agric. Scand. 20: 10-14.

Vázquez JAT, Posadas MV, Juárez HC and Montaldo HH (2009). Genetic and phenotypic parameters of milk yield, milk composition and age at first kidding in Saanen goats from Mexico. Livest. Sci. 126: 147-153.

Zeng SS and Escobar EN (1995). Effect of parity and milk production on somatic cell count, standard plate count and composition of goat milk. Small Rum. Res. 17: 269-274. 